\title{
Byens husmænd og andre overlejrede historier
}

\author{
Af Poul Sverrild
}

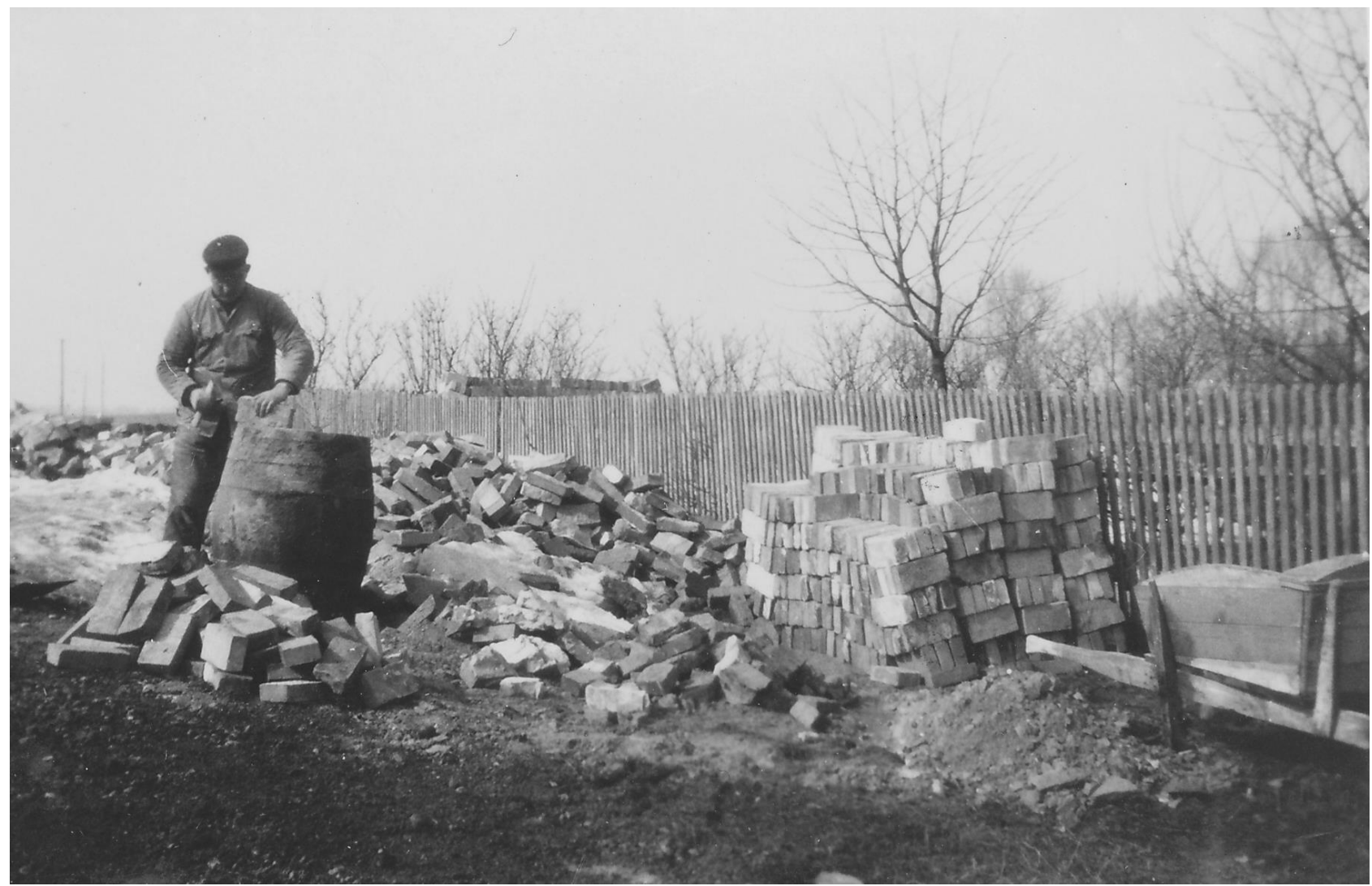

Gennem de første fire årtier af det 20. århundrede søgte tusindvis af javne danskere til byernes udkanter for at realisere drømmen om et bedre liv end det, som landet og byen bød på. Historien om titusinder af selvbyggere og deres indsats for at sikre enfamiliehuset pladsen som den mest elskede boligform er et eksempel på overlejrede historier. Selv om de i forhold til den dengang eksisterende boligmasse udgjorde en ligeså stor andel som en senere tids parcelhuse fra efterkrigstiden i forhold til den tids boligmasse, så er historien blevet den, at det var i efterkrigstiden almindelige danskere fik mulighed for at bo i eget hus. (Forstadsmusset)

$\mathrm{Vi}$ - de interesserede i byens og boligens historie - mener i almindelighed at den danske grundfortælling om urbaniseringen og dermed hovedtrækkene i by- og boligudviklingens historie er velkendt. Det er en fortælling, der er så alment udbredt, at den f.eks. er ideologisk fundament for både den almene boligsektor og samtidig for arkitektstandens forståelse af sit bolig- og planhistoriske grundlag, og den står grundlæggende uantastet i dansk byhistorie.

Det efterfølgende skal illustrere, hvordan den herskende forståelsesramme - baseret på bagudskuende kausalitetsforståelse af fortiden - har overlejret kræfter, tendenser og ideer, der i perioder spillede væsentlige roller i, men som altså ikke sejrede og derfor ikke blev levnet plads i fortællingen. Men altså fænomener, som alligevel har sat spor, som fortjener at blive fulgt, fordi de peger på alternative udviklingsretninger, som under lidt andre forhold kunne have været de sejrende og som under alle omstændigheder aktuelt kan inspirere os til at se nye udviklingsveje og muligheder. 
De fire cases, som eksemplificerer potentialet i de overlejrede historier, berører dels den almindelige parceludstykning, dels en glemt forening, som viser tilbage til parcelorganisationernes kulturelle tilknytning til de landlige kulturer, hovedparten af medlemmerne kom fra, dels forholdet mellem den tidlige almennyttige boligbevægelse og parcellisterne og endelig Mikkel Hindhede ${ }^{1}$, parcelbevægelsen og den teknikerstyrede samfundsudvikling.

En simplificeret typologioversigt antyder ultrakort rammerne om bolighistorien siden 1850, som vi almindeligvis sætter som begyndelsen på den moderne boligsektor. Med industrialiseringens urbanisering og den moderne arbejderklasses opståen som baggrundstæppe opstod det nye boligmarked, hvor voksende grupper selv skulle skaffe sig tag over hovedet. Det blev afsættet for de to nye boligformer, som altovervejende er kommet til at præge byernes vækst gennem de følgende halvandet hundrede år: På den ene side haveboligen for den enkelte familie, som selv kunne tage hånd om sin boligsituation og på den anden side lejligheden i boligblokken til arbejderklassen og de lavere mellemlag, som i den nye samfundsorden havde svært ved selv at sikre sine boligrammer. Fysisk og socialt har de naturligvis udviklet sig over decennierne, men som typologier har de grundlæggende holdt.

Anslaget kom i 1850’erne på Østerbro i København med den næsten synkrone udvikling af det borgerlige villakvarter 'Rosenvænget' for de selvhjulpne og med lægeforeningens arbejderboliger, 'Brumleby' på den nærliggende Øster Fælled, for den del af bybefolkningen, der ikke kunne selv. Den nye klart klasseinddelte urbane struktur, som kom til København med dette anslag, var placeret med få hundrede meters indbyrdes afstand. Arkitekten Gottlieb Bindesbøll, der skabte rammerne i Brumleby, tegnede interessant nok også villaer i Rosenvænget.

De to byggerier starter den knæsatte fortælling om den danske bolighistorie. Med afsæt i det filantropiske grundlag for Brumleby fortsætter den opbyggelige historie til 'Kartoffelrækkerne' ved Søerne i København, hvor den fremvoksende industriarbejderklasse nu i 1860'erne 'bare' skulle have hjælp-til-selvhjælp, så de i fællesskab kunne opføre deres egne boliger - en hjælp, der i øvrigt blev orkestreret af den samme gruppe læger mfl., som havde stået bag 'Brumleby'. Det er værd at erindre, at sideløbende med disse spinkle og ret enkeltstående initiativer blev den tidlige industrialiserings københavnske boligforbrug dækket gennem et omfattende og accelererende spekulationsbyggeri af lejlighedskomplekser på brokvartererne.

Den kanoniserede bolighistories tredje led er 1890'ernes lovgivning om statsstøtte til byggeforeninger, hvor fastansatte faglærte kunne få eget hus - typisk i en mindre have - ligesom de højere samfundsklasser. ${ }^{2}$

Det næste trin i den kanoniserede danske bolighistorie, følger introduktionen af det britiske havebybegreb. Her introduceres en række nye vigtige aktører i rummet mellem arkitektur, planlægning og boligpolitik, som indenfor en ret snæver personkreds skabte og skubbede til bevægelser, der på mange leder blev afgørende for hele den danske arkitekt- og planlæggerstands selvforståelse gennem det 20. århundrede. ${ }^{3}$ Gennem flere foreningsdannelser, via bebyggelsen 'Grøndalsvænge' og den parallelle spæde almennyttige boligbevægelse, begynder historieskrivningen og -forståelsen at dele sig op - men dog indenfor en fælles overordnet ramme. På den ene side følges den almene sektors betydning for boligarkitekturen og -historien gennem dens udstrakte brug af det 20. århundredes store arkitekter. På den anden side behandles enfamiliehuset gennem bedre byggeskikbevægelsen og efterfølgende modernismens avantgardistiske huse. Det tredje spor følger den fysiske planlægnings historie, som placerer de to første spor i en samlet fortælling, som peger frem mod velfærdsamfundets kulmination i 1970'erne. 
Ligesom det sene 1800-tals spekulationsbyggeri ikke fylder i bolighistorien, som andet end en negativ spejling af den gode historie, fylder det overvældende antal enfamiliehusene fra det 20. århundrede ikke - hverken i forhold til hverken deres antal eller deres overvældende succes. ${ }^{4} \mathrm{I}$ de seneste år er interessen for det 'almindelige' husbyggeris historie dog vokset, og den er for alvor ved at finde vej ind i litteraturen. ${ }^{5}$ Der savnes endnu en samlet fremstilling, som dækker hele spændvidden fra den selvgroede byggeskik over hverdagsarkitekturen til den artistiske arkitektur, og som forholder sig til bygningstypologiernes betydning for borgerne og ikke blot for de skrivende og læsende fagfolk.

Et af de store områder, der endnu savner kortlægning, er de mange tusinde statslånshuse fra perioden mellem 1938 og 1958, men i takt med den aktuelt accelererende interessenedsivning til mere almindelige dele af boligmassen må det forventes, at de første arbejder er på vej.

Så meget - eller så lidt - om den rammefortælling, som de efterfølgende cases skriver sig op mod.

\section{Spekulanterne}

Som eksempler på historier af generel betydning, der unddrog sig den brede bolighistoriske fortælling kan den helt særlige 'Eberts Haveby' fra 1890'erne i Sundbyvester på Amager trækkes frem, og tilsvarende kan en meget typisk storkøbenhavnsk udstyknings- og bebyggelseshistorie præsenteres af 'Risbjerggårds Villaby' i Hvidovre fra 1918.

'Eberts Villaby' er på den ene side den lokalhistorisk velkendte, at fabrikant Hermann Ebert som developer på det indre Amager ville skabe en villaby efter sin egen smag for de mere velstående klasser. Hans - ifølge en umiddelbar eftertid - mindre gode arkitektursmag er i dag blevet attraktiv for storbyens kreative klasser, ligesom beliggenheden på datidens 'Lorteø' nu mere end 100 år senere er blevet det. Historien om det uattraktive, der med tiden bliver attraktivt, er så velkendt, at den er banal, så det spændende ligger et andet sted i historien.

Kvarterets store villaer henvendte sig stilmæssigt til et borgerligt segment, men der var tilsyneladende ikke overensstemmelse mellem produktet og efterspørgslen. Det hang formentlig sammen med, at de klasser, Hermann Ebert ønskede at bygge for, ikke var interesseret i den del af storbyens sociale geografi, som Amager dengang repræsenterede.

Husene kunne derfor ikke sælges på de for tiden almindelige vilkår for borgerlige villaer, så Ebert måtte tilvejebringe en ny finansieringsform. Husene i 'Eberts Villaby' måtte som de første sælges på afbetaling. ${ }^{6}$

Det er finansieringsformen, som viste sig at være påkrævet for at få projektet på markedet, som bør påkalde sig en bredere interesse. Ikke bare fordi kvarteret præsenterede en ny finansieringsform på området, men fordi det var en form, som i det 20. århundrede blev normen for brede dele af befolkningen som middel til at få tilgang til også store forbrugsgoder, man ellers ikke umiddelbart havde råd til. Så Eberts særegne byggeprojekt påkalder sig interesse som et af mange bud i viften til det boligmarked, der i første halvdel af det 20. århundrede skulle løse industrisamfundets boligbehov.

'Historien om 'Risbjerggårds Villaby' er en diametral modsat historie. Her er det et helt almindeligt projekt af den slags, hvis form og forløb er blevet overlejret af fortællingerne om det særlige. I historien om de nye enfamiliehuskvarterer fra de første årtier af det 20. århundrede for de bredere samfundslag er det de få særlige projekter, der har fået plads i historien - selv om de ikke kom til at danne skole i overbevisende grad. 
I litteraturen er det ikke mindst udstykningsplanen for 'Vigerslev Haveforstad"7, man støder på som illustration af havebytænkningens indflydelse på udviklingen af det danske villakvarter. Som almindelighedens modstykke hertil kan vælges mellem et utal af udstykninger. 'Risbjerggårds Villaby' i Hvidovre blot et par kilometer fra udstykningen i Vigerslev er altså blot ét af utallige eksempler på det typiske forløb i perioden.

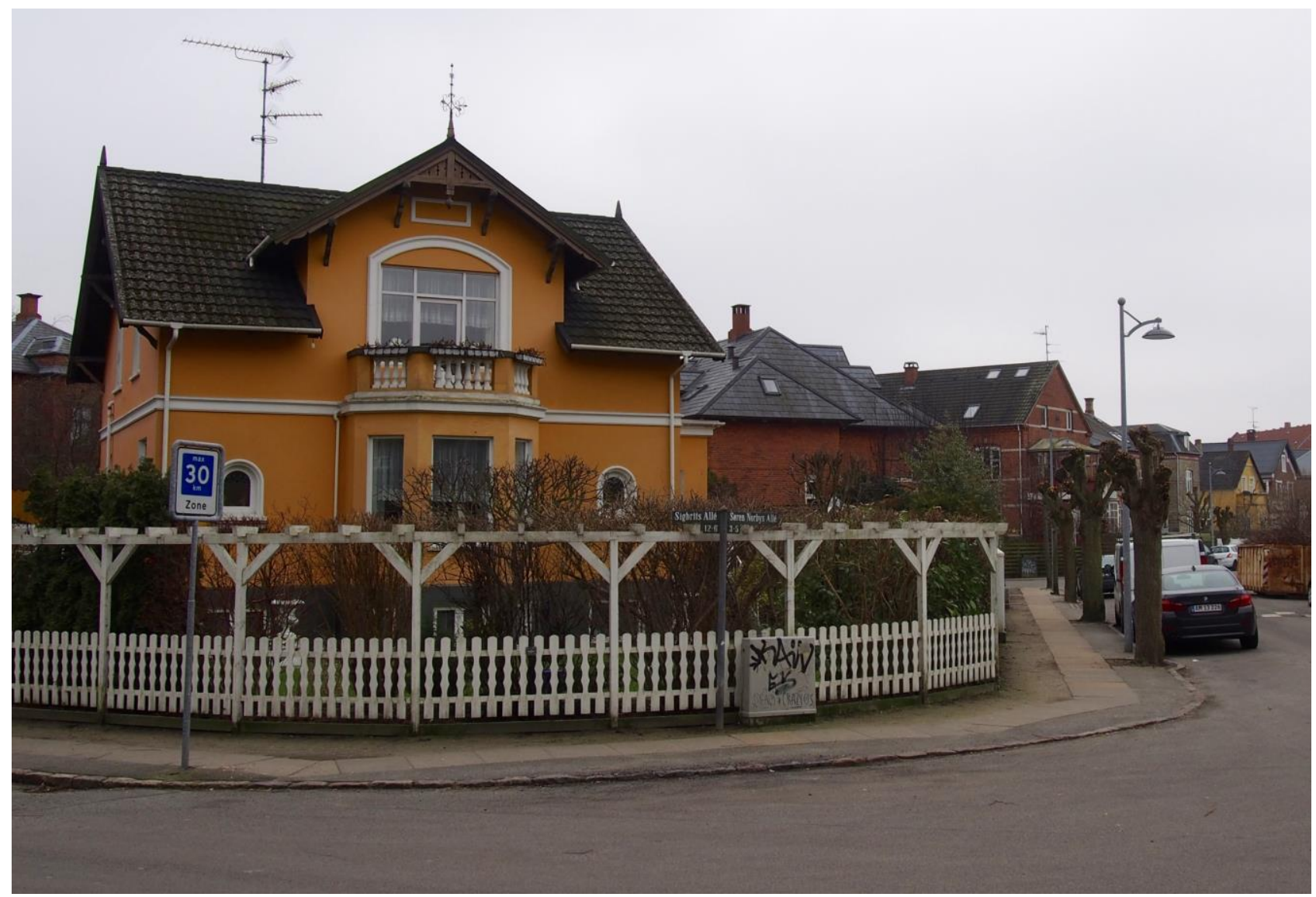

Eberts Villaby er enestående, men har varet barer af den 'forkerte' historie, så den er først meget sent begyndt at få den placering i bolighistorien, som projektet kan gфre krav på (Foto: Poul Sverrild)

Risbjerggård blev købt af en københavnsk overretssagfører med henblik på udstykning. Gårdens hovedmatrikel kunne give plads til ca. 280 parceller af standardstørrelse på mellem $700 \mathrm{og} 800 \mathrm{~m}^{2}$, idet en god tønde land omkring gårdens bygninger og et par hektar vandlidende eng mod Harrestrup $\AA$ ikke blev udstykket.

Udstykningen sikrede reelle rektangulære grunde og et retvinklet net af veje - her handlede det ikke om æstetik, men om hensigtsmæssighed. Grundene blev udstykket til samfundslag, der ville vide at skønne på, at jorden var pløjet forud for udstykning og salg, og som naturligvis satte pris på en høj bonitet. Det var byggegrunde, men det var også jordbrugsareal, køberne var interesserede i.

Den daværende landbrugslovgivning betingede, at for at landbrugspligten på gårdens jord kunne ophæves med henblik på udstykning, skulle sælger kunne præsentere en liste med købere. Det var i mange udstykninger selve baggrunden for, at der blev etableret en grundejerforening forud for eller parallelt med udstykningen. 
Altså intet ideelt formål, men en praktisk foranstaltning, som sikrede udstykkeren en vis kontrol med processen. Derfor ses i mange grundejerforeninger fra perioden, at udstykkeren eller hans repræsentant blev den første formand for foreningen. Målet med udstykningerne var entydigt spekulativt.

Det blev denne udformning af enfamiliehuskvarterer med 100.000'vis af huse, der blev normen i Danmark frem til 1960'erne. Her begyndte grundene mange steder blive mere kvadratiske, og samtidig vandt den amerikanske udstykningsform med lukkede stisystemer og fællesarealer at vinde frem. ${ }^{8}$

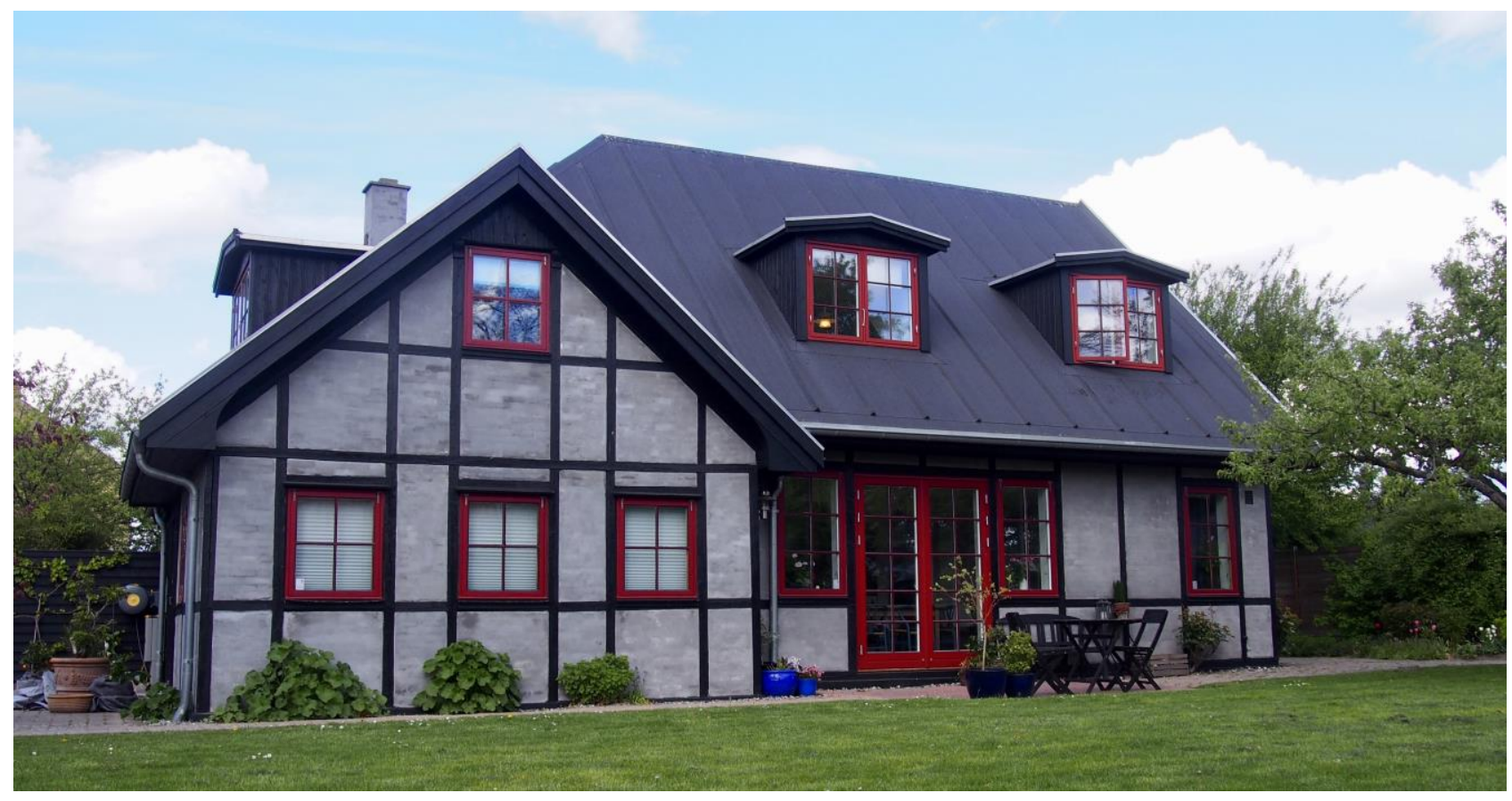

Et af de mere markante enfamiliehuse i Risbjerggårds Villaby tilhфrte formanden for centralforeningen, Jens Tybjerg. Han kфbte tre matrikler og lagde huset hen over skellet. Så det var ikke med henblik på senere frasalg, men med henblik på dyrkning, han sikrede sig en stor ejendom. Tybjerg anvendte ikke selv nogen af centralforeningens anbefalede hustyper. (Foto: Poul Sverrild)

\section{Byens Husmænd}

Som omtalt spillede matriklernes dyrkbarhed en rolle for mange købere ${ }^{9}$, hvis $\emptyset$ konomi pegede i retning af, at processen fra grundkøber til villaejer kunne blive langstrakt. Det er ikke den type småhusejere, der fylder i historieskrivningen, selv om de fylder i historien.

Den gængse tolkning af enfamiliehusets bymæssige fremvækst uden for de højere klasser fokuserer på social nedsivning, hvor overklassens og senere den $\emptyset$ vre middelklasses boligkultur blev kulturelt ideal for de lavere klasser, men det forekommer langt mere relevant for de første årtier af det 20. århundrede at fokusere på baggrundskulturen hos store grupper af de nye enfamiliehusejere. De kom fra landet og havde for manges vedkommende afsæt $\mathrm{i}$ jordbrugssamfundets jordløse klasser. De var vokset op i små og ydmyge længehuse, men dog i en ejerkultur. Husets have eller den tilhørende diminutive jordlod blev dyrket som en del af en todelt $\varnothing$ konomisk struktur, som på den ene side forudsatte lønarbejde for en del af familien og på den anden side krævede udbytte fra boligens jord - større eller mindre. 
Det var en kultur, de bragte med sig til byen og først og fremmest til de områder i byens periferi, hvor de kunne udfolde den medbragte kultur. I det lys bliver både bygge- og livsstilen for de titusindvis af jordlods-, lysthus- og husejere i årtierne omkring den 1. verdenskrig forståelig.

At denne oversete forståelsesramme var markant til stede i tiden dokumenteres af flere aktører. En kendt boligaktør i tiden som F.C.Boldsen, hvis indsats og holdninger til boligsagen på flere områder bestemt ikke er overset, har fået nedtonet sin lange konsistente indsats for mindrebemidlede husejere. Velkendt er hans tidlige indsats for husmandssagen, men ikke hans tilsvarende indsats for 'byens husmænd' - parcellisterne.

I sin person koblede F.C.Boldsen de to sider af boligbevægelsen, der senere i århundredet skulle blive antagonister: den almennyttige ide og selvejet. Begrebet 'byens husmænd' rummede en reference til blandt andet Boldsens indsats for husmændene omkring århundredskiftet. Den samme samfundsklasse var nu ankommet til byen og burde efter hans mening have samme støtte som var blevet landbosamfundets husmænd til del, og som kunne aflæses i husmandslovgivningen i tiden.

Boldsen engagerede sig markant i tidens store bevægelse på parcellistområdet i hovedstaden, 'Centralforeningen for Parcelforeninger og villaejere i København og Omegn'. Foreningen blev stiftet i august 1920 - samme år, hvor Boldsen blev direktør for det nystiftede almene boligselskab KAB.

Centralforeningen landede midt i den store bolignød i tiden efter den 1. verdenskrig, og Boldsen blev en stærk fortaler for sagen, som havde parcelejernes byggeforhold som omdrejningspunkt. Der var for mange krav og bestemmelser omkring småhusbyggeriet, som besværliggjorde adgangen til eget hus, og foreningens pointe var, at bolignøden ville blive minimeret, hvis alle parcelejerne hurtigt kunne komme til at bygge på deres grunde. Centralforeningen blev især talerør for eksisterende og kommende husejere fra samfundets lavere lag.

Foreningen, som knap er til at få øje på i litteraturen, nåede i begyndelsen af 1920'erne pænt op over 10.000 medlemmer i Københavnsområdet, så den var til at få øje på i samtiden. Interessant er det, at den geografiske fordeling af medlemmerne på Københavns omegn slet ikke modsvarer det billede, vi i dag har af omegnens sociale geografi. Den kommune, hvor tredieflest medlemmer havde deres grund, var Gentofte kommune - kun overgået af Hvidovre kommune og Københavns kommune. ${ }^{10}$ Det afdækker endnu en overlejring, hvor småkårsbefolkningens historie i Gentofte er blevet nedtonet af den senere sociale udvikling i kommunen.

I kølvandet på interessen for havebybevægelsen og væksten i småhusbyggeriet opstod en række foreninger, som både, skulle styrke og kvalificere interessen for området. Dansk Haveboligforening skulle fremme haveboligsagen i bred forstand, og i Foreningen Bedre Byggeskik ville danske arkitekter arbejde for at højne byggestilen i den lidt bredere bygningsmasse. Bedre Byggeskik er velbeskrevet i litteraturen - og fuldt berettiget.

Men interessen for den højprofilerede forening Bedre Byggeskik, som virkede for mellemlagene, har ganske overskygget den indsats, som centralforeningen øvede i Storkøbenhavn i begyndelsen af 1920 'erne. Foreningen udgav i 1922 et hæfte med modeltegninger af huse for mindre bemidlede bygherrer. ${ }^{11}$ Hæftet er gået helt i glemmebogen på tror af, at en del af husene var tegnet af de samme arkitekter, som var aktive i Bedre Byggeskik, og mange af hustyperne arbejdede indenfor samme arkitekturretning. Men centralforeningens huse blev, som nævnt, tegnet til lag i samfundet, som havde færre midler og mindre positiv eksponering end Bedre Byggeskik-segmentet. 
Parcellist-sagen kom i 1920'erne ikke til at opleve en politisk velvilje, der var parallel med den fremme, husmændene nød - byens husmænd blev forbigået politisk og siden overhalet af, at senere generationer af parcellister befandt sig i mentale rum, hvor bar overlevelse var erstattet af kulturelle/økonomiske ambitioner.
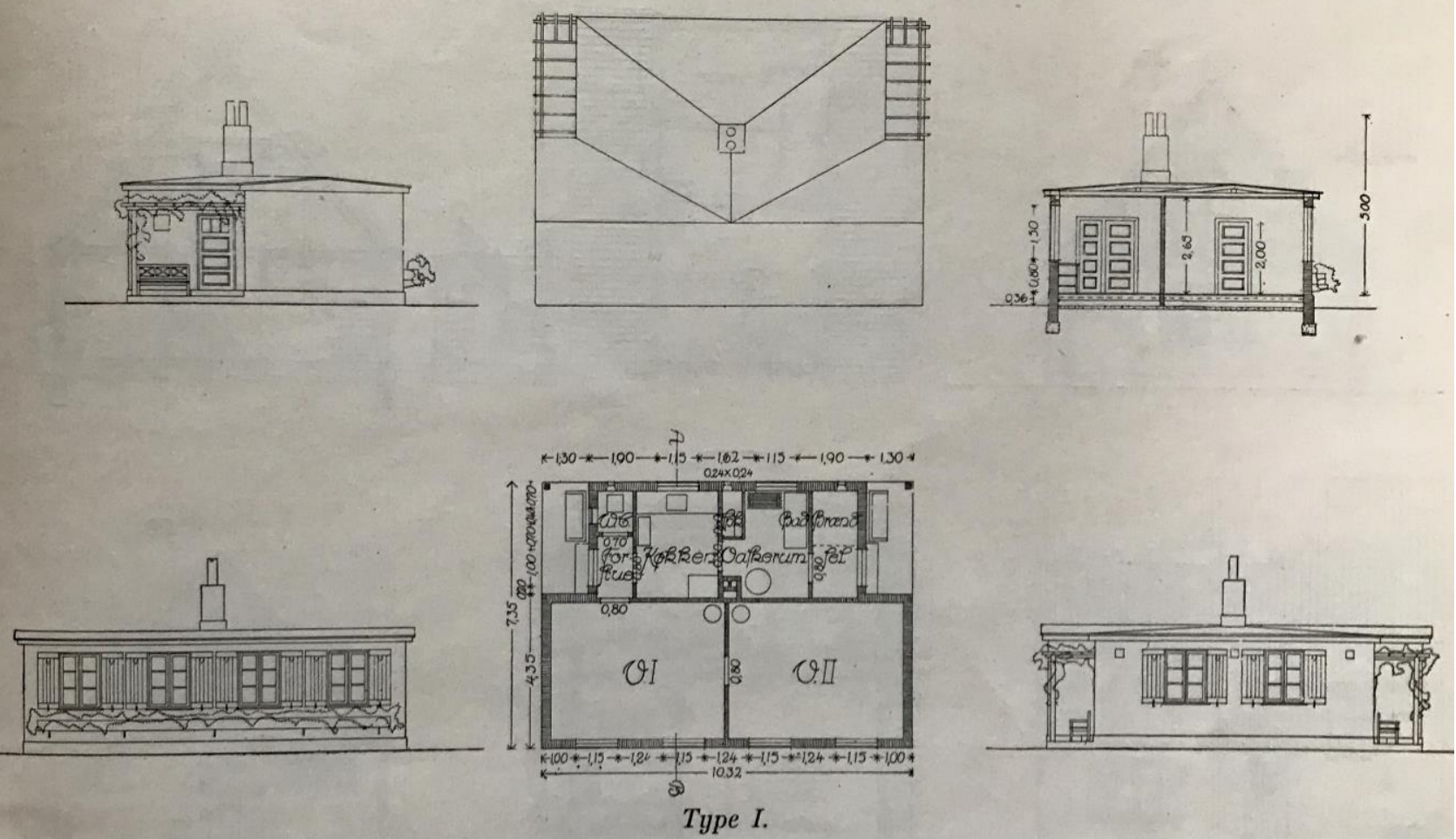

Arkitekt Anton Rosens bidrag til centralforeningens modelhafte var et enkelt og billigt hus. Huset, der barer inspiration fra landligt russisk almuebyggeri, skulle opvarmes med en finsk masseovn.

\section{Parcellisterne og det almennyttige}

En detalje i bolighistorien skal nævnes her som endnu et eksempel på overlejring. F.C.Boldsens varme interesse for parcellisterne trak han i begyndelsen af 1920'erne med over i sin nye stilling som direktør for KAB. For ham var småkårsfolks boligforhold væsentligere end de enkelte boligers $\emptyset$ konomiske organisering.

I samarbejde med centralforeningen oprettede F.C. Boldsen en funktion under boligselskabet KAB, som kunne hjælpe parcellisterne med at løse de problemer, som opførelse af eget hus indebar for mennesker, som hverken havde en teoretisk uddannelse eller var bærere af en urban kultur. KAB oprettede sågar et filialkontor i Hvidovre, og senere endnu et i Brønshøj, som alene rettede sig til byggelystne parcelejere. Fra filialkontorerne leverede man hjælp til flere hundrede husejere - både byggeteknisk, arkitektonisk og finansielt.

Det er en beretning man må lede længe, men stort set forgæves, efter i den righoldige litteratur om den almene boligbevægelse. Her har eftertidens boligpolitiske udvikling gjort fortællingen om fælles interesser og samarbejdet mellem lejere og ejere uhensigtsmæssig og uønsket. Tilsløringen af de oprindelige grundlæggende fællesinteresser på tværs af de bredere lags boligsituation har muliggjort udviklingen af en fastslået dikotomi boliglejere og boligejere imellem. Det har igen muliggjort en politisk proces, hvor den ene del af den fælles masse er blevet vinder og den anden taber, og det i en grad, så det i dag er svært at forestille sig, at historien kunne være blevet en anden. 


\section{Byggelaan, \\ Hjæelp til Indkøb af Materialer}

og enhver Art af $A$ s sistance eller $V$ ejledning ved Byggeri ydes ved Henvendelse til vort Hovedkonter, Vestervoldgade 8 (Kuntortid 10-3, Fredag til 6). Telefon 3767, 4667, 3748, eller til vort Filialkontor I Frihedskroen, Hvidovre, Mandag fra 7-8. Selskabet har ledet Opforelsen af over 600 Villaer i Kobenhavn og Omegn.

\section{Københavns almindelige Boligselskab.}

(Fuldt indbetalt Garantikapital $400,000 \mathrm{Kr}$.)

Parcellisternes ugeblad i Hvidovre reklamerede flittigt for KAB's tilbud til de håbefulde indehavere af endnu ubebyggede eller sommerhusbebyggede matrikler. (Parcellisten, 1928)

\section{Mikkel Hindhede}

Det andet lille eksempel, som skal nævnes her, peger på en fravalgt udviklingsmulighed i småhuskulturen, hvis både kort- og langsigtede konsekvenser potentielt har været omfattende.

Mikkel Hindhede, som netop har været genstand for en monografi nævnt i indledningen, var i 1920'erne ikke en hvem-som-helst. Manden bag ernæringspyramidens omlægning var også manden bag den vellykkede rationeringsbaserede ernæringssituation i Danmark under 1. verdenskrig, og han var manden, som under den 2. verdenskrig sikrede den britiske befolknings ernæring. Men han var også en ener som på områder havde så radikale træk, der kunne gøre ham til genstand for latterliggørelse.

Det var nu nok ikke hans personlige særheder, der stod vejen for, at han kom til på én gang at billiggøre byggemodningen for småhuse, nedsætte vandafledningen og ændre vores syn på vands rolle i forhold til saniteten.

I 1923 holdt han et foredrag, som blev til en artikel i Ugeskrift for Læger, om afløbsforhold ved sommerhuse. ${ }^{12}$ Her plæderede han for, at man i forbindelse med småhuse ikke behøvede kloakere, fordi der allerede fandtes et glimrende system til håndtering af toiletaffaldet. Systemet, som lugt- og smittefrit bragte affaldet i spil som gødning til havernes afgrøder.

Han henviste til, at systemet allerede var i spil i større udstykninger i Tyskland, og at det både ville muliggøre billigere ibrugtagning af småhuse fordi man sparede kloakeringen og styrke fødevareproduktionen i den mindrebemidlede del af befolkningen. Hindhede var på dette tidspunkt oppe mod hele faggrupper som ingeniører, arkitekter og læger, der havde investeret deres faglighed i de kloakeringssystemer, som i dyre domme var blevet implementeret i de danske byer. 
I dag ville forslaget måske møde større interesse - dels fordi dagsordenerne er forandrede, men også fordi andre faggrupper har overtaget store dele af den fysiske planlægning.

\section{Summary}

This lecture-based article was inspired by my thesis 'Periurban Phase and Sphere'. ${ }^{13}$ Among the observations of the study is that taking your point of departure in the time and space of the object of study, affects the outcome. You get different insights and reach different conclusions. In this case forgotten actors and ideas surface as the consequence of taking stand in a periurban hase and sphere. It reveals what and who lost and what would soon be overlaid after the struggle between ideas and cultures.

The first decades of the twentieth Century witnessed the suburbanization of huge areas round Copenhagen, while ideas and ideals of urban planning, housing and home-ownership were developed along the way. In this process on one version of history survived for generations, but the other sides reserve to be revealed. To shed light on them makes it possible not only to reconsider history but it may also point to new ways to work with todays challenges.

The shortlived and soon forgotten alliance between the social housing sector and the house-owners was a such possibility.

Similarly the strategies of Dr. Hindhede would by alternative handling of human manure both strengthen the production of food in housing-areas and minimize the land development costs. Adoption of his ideas would radically have changed our ways of urban development and housing.

The mentioned examples are - exactly - examples. Other studies based on the premises of time and space will reveal other overlayed phenomenons, which by their illumination may strengthen and clarify the foundations of todays and tomorrows decisions. Finally local variations gain more weight this way - and that by itself makes it worth it.

\section{Litteratur}

Millech, K. m.fl.: Dansk arkitekturhistorie, 1948

Dragsbo, P.: Hvem opfandt parcelhuskvarteret, 2014

Bidstrup, K.: Ebenezers disciple - fra dansk byplanlægnings pionertid, 1971

Lind, O. og Møller, J.: Alle tiders parcelhuse, 2014

Møller Andersson, V.: Dansk arkitektur i 1960’erne, 2019

Haveboligen, 1922

Centralforeningen for Parcelforeninger og villaejere i København og Omegn, Halvtres Haveboliger, 1921

Parcellisten, 1928

Ugeskrift for Læger, 1923, Nr. 25, særtryk. Hindhede, M. Afløbsforhold ved Haveboligen, Sommerhuse etc.

Sverrild, P.: Periurban Phase and Sphere - an investigation into the urbanization of the Copenhagen suburb Hvidovre, 2016

\section{Noter:}

\footnotetext{
${ }^{1}$ Halse, S. og Henschen, D. Mikkel Hindhede og kampen om danskernes kost, 2019, var ikke udkommet, da foredraget, der er artiklens forlæg, blev holdt.

${ }^{2}$ Denne del af bolighistorien er i arkitektur- og kulturhistorielitteraturen beskrevet i grundlæggende overensstemmende lys fra Millech, K. m.fl. Dansk arkitekturhistorie, 1948 til Dragsbo, P. Hvem opfandt parcelhuskvarteret, 2014.

${ }^{3}$ Bidstrup, K. Ebenezers disciple - fra dansk byplanlægnings pionertid, 1971.

${ }^{4}$ Lind, O. og Møller, J. Alle tiders parcelhuse, 2014 og Dragsbo, P. Hvem opfandt parcelhuskvarteret, 2014, kaster som de første lys over enfamiliehusenes brede historie, men fortsat med afsæt i den kanoniserede bolighistorie og en underliggende forståelse af, at det danske enfamiliehuskultur primært repræsenterer en kulturel nedsivning.
} 


\footnotetext{
${ }^{5}$ Aktuelt f.eks.Møller Andersson, V. Dansk arkitektur i 1960’erne, 2019

${ }^{6}$ http://www.kulturarv.dk/1001fortaellinger/da_DK/eberts-villaby/images/newest/1/dt006454-20ca-201916-jpg-1

${ }^{7}$ Udstykningsplan fra 1914 for en stort område mellem Harrestrup Å i vest, Valby Langgade i Nord, den københavnske godsbane i øst og Roskildebanen i Syd udviklet af arkitekt Charles I. Schou. Inspirationen fra den britiske haveby er tydelig i vejplanerne med utallige lukkede veje, ståpladser og snoede vejforløb. Der kan ikke påvises nogen væsentlig afsmitning herfra på de snesevis af efterfølgende udstykninger i denne del af København og omegn.

${ }^{8}$ Udstykningsformen blev først kendt fra byen Radburn i New Jersey, hvor udstykningerne i denne form begyndte i 1929. Så forsinkelsesfaktoren i forhold til Danmark var markant.

${ }^{9}$ Mange faktorer spillede ind her: afsmitning fra kolonihavekulturen, fødevaremangel og dyrtid under og efter den 1. verdenskrig og ikke mindst den lidt oversete kulturelle faktor i flertallet af grundkøbernes baggrund i landbokulturen.

${ }^{10}$ Haveboligen, 1922.

${ }^{11}$ Centralforeningen for Parcelforeninger og villaejere i København og Omegn, Halvtres Haveboliger, 1921

${ }^{12}$ Ugeskrift for Læger, 1923, Nr. 25, særtryk. Hindhede, M. Afløbsforhold ved Haveboligen, Sommerhuse etc.

${ }^{13}$ Sverrild, P. Periurban Phase and Sphere - an investigation into the urbanization of the Copenhagen suburb Hvidovre, Aalborg University, 2016
} 